\title{
Małgorzata Rutkiewicz-Hanczewska
}

Uniwersytet im. Adama Mickiewicza w Poznaniu

\section{Semantyka nazw wlasnych $w$ ujęciu neurolingwistycznym ${ }^{1}$}

\section{Wstęp}

Semantyka nazw własnych jest jednym z istotnych problemów nie tylko językoznawstwa, a dokładnie onomastyki, lecz także neuropsychologii czy neurokognitywistyki. Znane są sprzeczne hipotezy na temat znaczenia nazw własnych. Według jednych nazwy własne są pozbawione znaczenia (meaningless thesis). Zdaniem Kripkego [1980] nazwy własne jako proste (sztywne) desygnatory mają stały i jednostkowy związek z danym referentem, a źródłem referencji nie jest myśl o danym obiekcie, ale łańcuch komunikacyjny utrwalony tradycją sięgającą nadania danej nazwy. Pogląd o braku znaczenia nazw własnych w ujęciu terminów denotacja i konotacja po raz pierwszy został sformułowany przez Milla [1843]. Jego zdaniem nazwy własne denotuja, ale nie konotują.

Pojęcie konotacji (w tym denotacji) precyzowali kolejni filozofowie, m.in. Russell [1919], który nazwy własne uznawał za skrócone deskrypcje określone. W jego rozumieniu znaczenie nazwy własnej to zespół asocjacji wiązanych przez mówiącego $\mathrm{z}$ nazywanym obiektem. Zatem nazwy własne pełnią funkcje referencjalną z uwzględnieniem zbioru deskrypcji określonych (backing of description thesis). Te zdaniem Searle'a [1971] jako zbiór cech przypisywanych danemu obiektowi rozmówca powinien umieć stosować wymiennie z nazwą własną, co jest warunkiem właściwego jej użycia.

Współczesne badania onomastyczne nad istotą nazw własnych pokazują, że nazwy własne zarówno denotują jak i konotują. Powstają słowniki eponimów [Beeching 1982; Freeman 1997] i konotacji nazw własnych [Otin 2004; Rutkowski 2012]. Nazwy własne w konkretnym tekście zaczynają znaczyć. Te znaczenia tworzy się z wykorzystaniem mechanizmów metonimii lub metafory [Glucksberg, Haught 2006] bądź elementów pośrednich [Goosens 1990].

${ }^{1}$ Artykuł powstał w ramach projektu badawczego nr UMO-2011/01/B/HS2/02479. 
Zatem już dla filozofów i językoznawców poziom semantyczny nazw własnych stanowił i stanowi przedmiot dyskusji. Neuropsychologowie i neurokognitywiści ten poziom analizują w kategoriach umożliwiających wyjaśnienie mechanizmu anomii ${ }^{2}$ proprialnej [Semenza, Zettin 1988, 1989], czyli zaburzeń przywoływania odpowiednich nazw własnych, towarzyszących afazji, która oznacza „dezintegrację procesu przetwarzania informacji, czyli zaburzenie zdolności »dekodowania« i lub »kodowania« różnorodnych symboli niejęzykowych i/lub językowych występujących w danym języku, kręgu kulturowym czy wspólnocie komunikatywnej" [Pąchalska 2011: 27]. Zaburzenia afatyczne wywołane są destabilizacją systemów mózgowych w następstwie różnorodnych uszkodzeń mózgu, powstałych wskutek chorób naczyniowych (udar mózgu), zmian nowotworowych, chorób neurodegeneracyjnych, zatruć, procesów zapalnych czy urazów czaszkowo-mózgowych.

Neurokognitywiści pojęcia konotacja i denotacja zastępują terminami: semantyka jednostkowa (individual) oraz semantyka ogólna (general). Zasadniczo oba te poziomy semantyki należą do istotnych i biorą udział w procesie produkcji oraz funkcjonowania, użycia rzeczowników własnych. Najwyraźniej są ze sobą w pewien sposób powiązane. Interesujące jest to, jakiego to rodzaju więź i czy mechanizmy ustrukturyzowania obu typów semantyki (konotacji i denotacji) są podobne. Innymi słowy, czy nazwę własną można wyszukać bez dostępu do poziomu denotacyjnego lub konotacyjnego, jak przebiega takie wyszukiwanie z uwzględnieniem różnych bodźców: wzorkowego, znakowego (zapis nazwy), słuchowego (podanie cech semantycznych)? Czy można mówić o lokalizacji mózgowej proprialnego znaczenia denotacyjnego i konotacyjnego?

\section{Wyjątkowość nazw własnych - podwójna dysocjacja (anomia proprialna i apelatywna)}

Na przedstawione pytania usiłujemy odpowiedzieć podczas prowadzonych w naszym ${ }^{3}$ laboratorium eksperymentów. Dziś trudno określić, czy i kiedy uda się udzielić jednoznacznej na nie odpowiedzi. Kolejne próby zbliżają

${ }^{2}$ Anomia bez względu na rodzaj (proprialna czy apelatywna) jest rodzajem deficytu, który polega na trudności lub niemożności w przywoływaniu nazw, w wydobywaniu ich ze słownika mentalnego.

${ }^{3}$ Badania są prowadzone w Klinice Neurologii i Chorób Naczyniowych Układu Nerwowego Katedry Neurologii Wydziału Lekarskiego i Uniwersytetu Medycznego im. Karola Marcinkowskiego w Poznaniu ZOZ MSWiA w Poznaniu im. prof. L. Bierkowskiego. Prezentowane w artykule wyniki pochodzą z analizy jednego przypadku anomii proprialnej (badania pilotażowe). Uogólnione wyniki badań zostaną opublikowane po zakończeniu projektu badawczego pt. „Procesy aktualizacji nazw własnych i pospolitych w obrazie zaburzeń językowych pochodzenia neurologicznego (afazja, dyspragmatyzm, zaburzenia języka w chorobach neurodegeneracyjnych)”. 
badaczy do celu, a ponieważ podejmuje się je od niedawna, wyniki mogą być obiecujące.

Neuropsychologia nazw własnych jest przedmiotem szczególnego zainteresowania naukowców dopiero od schyłku lat 80. ubiegłego wieku [Semenza 1997], kiedy zaobserwowane zostało zjawisko tzw. podwójnej dysocjacji, polegające na współistnieniu dwu lustrzanych deficytów w zakresie wyszukiwania nazw własnych i pospolitych, a mianowicie: na zachowanej zdolności wyszukiwania rzeczowników własnych przy zaburzeniach aktualizowania nazw pospolitych i wzorcu odwrotnym, zachowaniu zdolności nazywania propriów przy zaburzonej zdolności aktualizowania nazw pospolitych [Valentine, Brennen, Brédart 1996; Cipolotti 2000; Lyons, Hanley, Kay 2002; Schmidt, Buchanan, Semenza, 2004; Martins, Farrajota 2007]. Ta obserwacja skłoniła naukowców do postawienia tezy o odrębnych mechanizmach dostępu do nazw własnych i pospolitych [Martins, Farrajota 2007; Semenza 2006, 2009]. Obecnie sądzi się, że procesy nazywania rzeczowników własnych i pospolitych przebiegają odrębnymi szlakami, mieszczą się w odrębnych strukturach mózgowych. Ponieważ anomia apelatywna i proprialna jest zdecydowanie odmienna, tzn. ujawnia się z różnym nasileniem i wiąże się z odmienną lokalizacją uszkodzenia mózgowia, uznaje się że rzeczywistość neuronalna dowodzi odrębności nazw własnych i ich wyjątkowości w zestawieniu z nazwami pospolitymi [Robson, Marshall, Pring, Montagu, Chiat 2004: 917; Semenza 2009: 347].

\subsection{Poziomy wyszukiwania nazw własnych (anomia proprialna)}

Specyfika nazw własnych skłoniła badaczy do zastanowienia się nad sposobami aktualizowania nazw własnych. Powstało kilka modeli ich wyszukiwania [Valentine, Brennen, Brédart 1996], uwzględniających różny charakter zaburzeń aktualizowania propriów. W konsekwencji opisano kilka poziomów ich wyszukiwania [por. Schmidt, Buchanan, Semenza 2004; Semenza 2009].

Zasadniczo wyodrębnia się dwa: semantyczny oraz fonologiczny [Valentine, Brennen, Brédart 1996]. Na podstawie badań neuroobrazowych mózgu (np. PET) oraz obserwowanych zaburzeń mowy można mówić o systemie przekaźników dwutorowych (por. rys. 1), którego uszkodzenie daje dwukierunkowy defekt, polegający na tym, że w anomii dochodzi bądź do upośledzenia wyszukiwania danej nazwy (pospolitej lub własnej) przy możliwości podania wiedzy konceptualnej, bądź do sytuacji odwrotnej, a mianowicie upośledzenia wyszukiwania wiedzy konceptualnej z możliwością podania docelowego wyrazu [Tranel 2009]. Zatem możemy mówić o przynajmniej dwu niezależnych ścieżkach wyszukiwania propriów: o dostępie do danej formy wyrazowej (name, naming, poziom fonologiczny) oraz do wiedzy na temat związku nazwa - referent (meaning, knowing, poziom semantyczny). 




Rys. 1. Schemat ujawniania się systemu przekaźników dwutorowych (two-way defect system)

\subsection{Poziom semantyczny i jego struktura}

Charakter wyszukiwania nazw własnych najlepiej ujawnia się podczas zaburzeń językowych o typie afazji ze współwystępującą anomią. Przybiera wówczas postać całkowitej niemożności przywołania wskazanego na schemacie typu wiedzy (na temat o kimś, o czymś? lub kto? co?) bądź tylko jego częściowej prezentacji (por. rys. 2.)

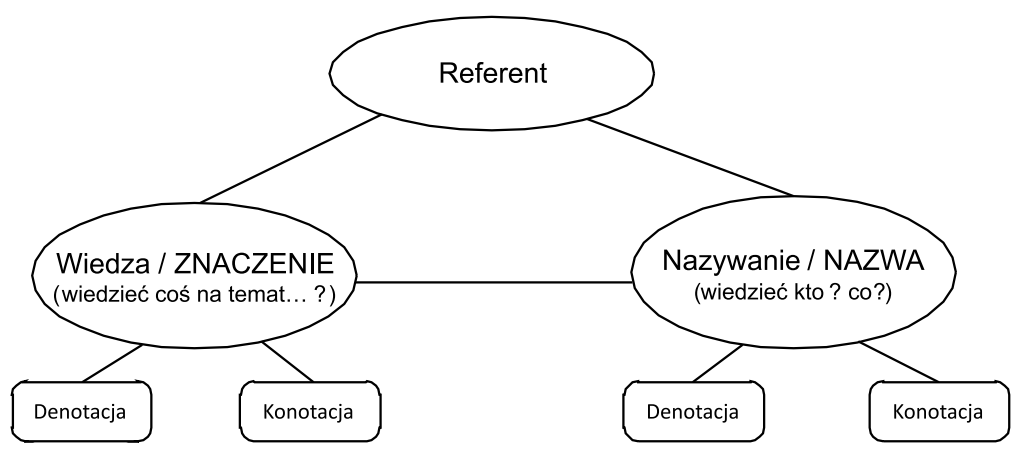

Rys. 2. Modelowa reprezentacja poziomów wyszukiwania nazw własnych i ujawniania się typów wiedzy

Każdy chory (z anomią) usiłuje radzić sobie na miarę własnych możliwości. W konsekwencji mamy do czynienia z różnymi formami kompensowania deficytów anomicznych. Badani różnymi modalnościami ${ }^{4}$ ujawniają fragmenty wiedzy

${ }^{4}$ Szerzej werbalne i niewerbalne sposoby kompensowania deficytów wyszukiwania nazw własnych (a także pospolitych) omawia Rutkiewicz-Hanczewska [2014]. 
konceptualnej na temat referenta lub/i znaku, który do niego odsyła. Przykładowo zamiast nazwy Jan Pawet II mówią papież (denotacja z poziomu znaczenie), a słowami nie lubię go, ten ... wskazują antroponim Lepper (konotacja z poziomu znaczenie). Z kolei w miejsce nazwy Doda pokazują cztery palce ręki na oznaczenie 4 liter, z których składa się docelowa nazwa (denotacja z poziomu znak), a przywołaniem leksemu zielony odwołują się do etymologicznego znaczenia nazwiska Verdi [Green[s] za: Semenza, Zettin 1988: 718] (konotacja z poziomu znak).

Dzięki formom kompensacji niedostatków nazywania można próbować zilustrować poziomy wiedzy semantycznej i ich wzajemne uwikłanie w procesie wyszukiwania nazw własnych. Porównania daje się dokonać na trzech płaszczyznach: w sytuacji, kiedy tę wiedzę ma wywołać prezentacja obrazu referenta (referent - znaczenie), podanie nazwy (relacja nazwa - znaczenie) oraz wskazanie samej wiedzy na temat referenta (relacja znaczenie - nazwa).

W niniejszym opracowaniu zajmiemy się dokładnym opisem tylko wiedzy ujawnianej na podstawie relacji: referent - nazwa (realizowanej w postaci referent - wiedza o nim) oraz nazwa - wiedza o referencie, do którego ten znak odsyła. Pozostałe bowiem sposoby prezentacji wiedzy nie stanowiły dla badanego problemu. Zostały wykonane w $100 \%$ prawidłowo. Mowa o testach wielokrotnego wyboru, w których należało połączyć fotografię z odpowiadającym jej nazwiskiem zapisanym na etykiecie. Badany poprawnie i wyjątkowo szybko dopasował zdjęcia określonych osób do ich podpisów. Oznacza to, że obraz referenta łatwiej skojarzyć z jednocześnie prezentowaną mu nazwą aniżeli wydobyć ją na polecenie ze słownika mentalnego. Także test wskazywania obrazu referenta na podstawie definicji został wykonany prawidłowo. Zatem chory ma dostęp do wiedzy semantycznej na temat denotatu. Zaburzona jest ścieżka wyszukiwania na poziomie tzw. postsemantycznym, w dostępie do leksykonu fonologicznego (post-semantic proper name anomia). To najpowszechniejszy model anomii proprialnej [Valentine, Brennen, Brédart 1996: 172; Semenza 2009: 351-352].

\subsubsection{Relacja obraz (referent) - nazwa}

W anomii proprialnej dochodzi najczęściej do upośledzenia przywoływania nazw prezentowanych obiektów. Wtórnie jednak następuje aktywacja innej ścieżki odwołania do znaku, jakim jest nazwa własna, a mianowicie uaktywnia się w formie kompensacji wiedza na temat referenta. Może to być dwojakiego rodzaju wiedza, ogólna lub szczegółowa, tzw. znaczenie denotacyjne lub konotacyjne (asocjacje związane $\mathrm{z}$ referentem).

W naszym eksperymencie ${ }^{5}$ zjawisko anomii proprialnej poddane zostało ocenie podczas prezentacji 102 fotografii obiektów oznaczonych nazwą własną.

${ }^{5}$ Badany prawidłowo przywoływał nazwy pospolite, a zatem nie cierpiał na anomię apelatywną. 
Wśród nich znalazły się przede wszystkim nazwy osobowe, których aktualizację najłatwiej poddać ocenie ze względu na ogólną wiedzę badanych osób. Do wyszukiwania nazw miejscowości wykorzystano pustą mapę Polski z zaznaczonymi granicami województw, w które chory miał wpisać nazwy stolic tych województw ${ }^{6}$.

Podczas tego eksperymentu ujawniła się różnica w sprawności aktualizowania nazw osobowych w stosunku do nazw geograficznych ${ }^{7}$. Dla poddanego badaniu problemem było aktualizowanie antroponimów. Chory był w stanie nazwać kilka prezentowanych mu fotografii $(8,57 \%)$, z czego część były to nazwy powszechnie znanych i utrwalonych w świadomości postaci typu: Hitler, Stalin, Tusk, Lis, Miś Uszatek. W aktualizacji nazw geograficznych osiagnął wynik na poziomie $40,62 \%$.

W próbach aktualizowania nazw osobowych relacja wiedza-nazywanie (por. rys. 2) przedstawiała się na niekorzyść nazywania. Chory przywołał nazwę (prawidłową lub nieprawidłową) 10 razy. W 25 przypadkach nie udzielił żadnej odpowiedzi. Wiedza z poziomu kto? co? ujawniała się także w formie komunikacji niewerbalnej w rodzaju pantomimy (gest składania rąk do modlitwy zamiast nazwy Popiełuszko) lub gestów typu wskazywania na liczbę liter składających się na daną nazwę.

Większość uzyskanych odpowiedzi pochodziła z poziomu wiedza o czymś. Chory aż 35 razy usiłował w zastępstwie szukanej nazwy wskazać cechy semantyczne referenta owej nazwy. Najczęściej ta wiedza miała charakter konotacji (15). W odpowiedziach pacjenta pojawiały się także cechy z zakresu denotacji (11). Swoją reprezentację uzyskały również (chociaż w mniejszym wymiarze) zarówno konotacja, jak i denotacja (9). To oznacza, że zaburzona relacja od obrazu denotatu do nazwy aktywuje wiedzę głównie z poziomu asocjacji. Denotowanie jest nieznacznie rzadziej ujawniane. Sporadycznie pojawiają się oba rodzaje wiedzy jednocześnie (por. tab. 1). Niewykluczone, że obraz referenta (bodziec wzrokowy) pozwala łatwiej wskazać cechy niedefinicyjne obiektu.

Teoretycznie podczas zastępczego aktualizowania poziomu wiedzy o czymś (zamiast nazwy) chory mógł podawać ją w 9 kombinacjach z wykorzystaniem następującego zestawu: a) podanie tylko denotacji; b) podanie tylko konotacji; c) podanie denotacji oraz konotacji. Podczas eksperymentu w odpowiedziach badanego ujawniło się 7 możliwości korzystania ze znaczenia denotacyjnego i konotacyjnego. Nie wystąpiły tylko 2 sytuacje: prawidłowa denotacja z nieprawidłową

${ }^{6}$ Tego rodzaju testy należą do standardowych w badaniu anomii. W miarę możliwości uwzględniają one stan wiedzy sprzed zachorowania badanego. Zawsze jednak istnieje obawa, że ten stan mógł być lepszy lub gorszy.

${ }^{7}$ Zaznaczona różnica w stopniu trudności aktualizowania nazw osobowych i geograficznych należy do specyficznych w testach z zakresu anomii proprialnej [Valentine, Brennen, Brédart 1996: 116; Semenza 1997: 130]. 
konotacją oraz nieprawidłowa zarówno konotacja, jak i denotacja. Z kolei wśród pojawiających się układów odpowiedzi częściej występowała odpowiedź z nieprawidłową denotacją, nieprawidłowa konotacja wystapiła tylko w jednym układzie ze współtowarzyszącym brakiem denotacji. Być może błędy w aktualizowaniu wiedzy nie dotyczą znaczenia konotacyjnego, a raczej poziomu denotacji. Ona jest trudniejsza do wydobycia ze słownika mentalnego.

Tabela 1. Kombinacje odpowiedzi dla relacji referent - wiedza (bodziec w postaci fotografii)

\begin{tabular}{|c|c|c|c|}
\hline Denotacja & Konotacja & $\begin{array}{c}\text { Występuje (W) } \\
\text { Nie występuje (NW) }\end{array}$ & Przykłady \\
\hline+ & + & W & $\begin{array}{c}\text { prezydent, dwie kadencje pełnił, jego } \\
\text { żona... (Kwaśniewski); wiem to jest, } \\
\text { ona pod prawie } 80 \text { podchodzi, ona } \\
\text { była śpiewaczką (Santor); to jest ten } \\
\text { słynny narciarz, co skończył karierę } \\
\text { (Małysz) }\end{array}$ \\
\hline+ & - & W & $\begin{array}{c}\text { to jest śpiewaczka (Górniak); to jest } \\
\text { też ten bokser (Adamek) }\end{array}$ \\
\hline+ & nieprawidłowa & NW & \\
\hline- & + & W & $\begin{array}{c}\text { nie lubię go, ten... (Lepper); } \\
\text { ten, co podpadł... (Palikot); } \\
\text { ten, co zginął, co go tam utopili, no } \\
\text { właśnie ten, jego mama jeszcze żyje } \\
\text { (Popiełuszko); w tym słynnym filmie } \\
\text { występował (Mikulski) }\end{array}$ \\
\hline- & - & $\mathrm{W}$ & \\
\hline- & nieprawidłowa & W & też śpiewa... (Schwarzenegger) \\
\hline nieprawidłowa & + & W & $\begin{array}{c}\text { to też był aktor, czy tam, wieczorem } \\
\text { zawsze występuje (Wojewódzki) }\end{array}$ \\
\hline nieprawidłowa & - & W & to jest aktor? (Wajda) \\
\hline nieprawidłowa & nieprawidłowa & NW & \\
\hline
\end{tabular}

Źródło: opracowanie własne.

\subsubsection{Relacja nazwa - wiedza}

W drugim eksperymencie chory otrzymał ułożoną alfabetycznie listę 85 nazw własnych, wśród których znalazły się takie kategorie, jak: imiona, nazwiska oraz nazwy miast, kontynentów, rzek, gór. Zadanie chorego polegało na pisemnym 
podaniu znaczenia tych wyrazów. Polecenie, jakie usłyszał chory, brzmiało: co znaczy ten wyraz? co znaczq te wyrazy? Celem tego testu była ocena wiedzy semantycznej pacjenta, którą miał wywołać bodziec w postaci znaku językowego (nazwy własnej), nie obrazu. Charakterystyczny okazał się prawie regularny brak odpowiedzi dla nazw osobowych (udało się udzielić odpowiedzi dla jednej nazwy - Einstein) oraz całkowity brak odpowiedzi dla kategorii nazwy gór i pasm górskich. Co istotne, badany prawidłowo przywoływał wiedzę dla nazw rzek, miast i kontynentów. Była to wiedza kategorialna, typu: rzeka, kraj, miasto, kontynent, imię. Nie pojawiały się tu wypowiedzi charakteryzujące cechy niedefinicyjne referenta, zatem nie ujawniło się ani razu znaczenie konotacyjne nazw.

W tym rodzaju eksperymentu znacznie uboższa okazała się liczba konfiguracji potencjalnie ujawnianej wiedzy o charakterze konotacji i denotacji. Wystąpiły tylko dwie relacje: obecność denotacji przy braku konotacji oraz brak zarówno jednej, jak i drugiej. Oznaczać to może, że relacja od znaku do wiedzy aktywuje $\mathrm{u}$ badanego konsekwentnie znaczenie kategorialne, z czego regularnie dla pewnych kategorii brakuje wypełnienia. Nie jest ono kompensowane wiedzą o charakterze konotacji (asocjacji).

W celu porównania ten fragment eksperymentu przeprowadzono także na grupie kontrolnej zdrowych oraz innych afatyków bez anomii proprialnej. Grupa kontrolna zdrowych w wieku od 20-23 lat ujawnia wiedzę zarówno kategorialną, jak i konotacyjna, grupa kontrolna powyżej 40 roku życia ujawnia wiedzę głównie denotacyjną z niższym stopniem udziału znaczenia konotacyjnego. Z kolei grupa kontrolna chorych (z oddziału internistycznego), lecz bez zaburzeń afatycznych, ujawnia głównie znaczenie denotacyjne. Może to dowodzić wagi znaczenia konotacyjnego propriów, które wraz z wiekiem użytkowników języka coraz trudniej aktualizować ${ }^{8}$. Nie można odrzucić również tezy, że znaczenie propriów przywoływane na podstawie nazwy wymaga przede wszystkim kategoryzacji (wiedzy kategorialnej). Wysiłek do jej odtworzenia nie pozwala na dalsze przeszukiwanie słownika mentalnego w celu wskazania znaczenia asocjacyjnego.

\section{Wnioski}

Semantyka nazw własnych jest przedmiotem szczególnego zainteresowania, ponieważ w jej specyfice upatruje się przyczyn trudności w aktualizowaniu nazw własnych (przy dość dobrze zachowanej zdolności produkowania nazw

${ }^{8}$ Badacze sądza, że wyszukiwanie nazw własnych jest zadaniem dużo bardziej wymagającym dostępu do energii, jeśli chodzi o metabolizm mózgu, niż wyszukiwanie nazw pospolitych. Spadek możliwości sprawnego wyszukiwania propriów zwiększa się z wiekiem (po 65. roku życia), a najsilniej ujawnia się w chorobie Alzheimera. Zauważono również, iż dwutygodniowa ekspozycja na wysokości 5000 metrów wywołuje znaczne pogorszenie przypominania sobie nazw własnych. Ten efekt trwa przynajmniej cztery tygodnie po powrocie na wysokość poziomu morza [Semenza 2009: 363-364]. 
pospolitych). Współczesne badania poświęcone są różnicy w wyszukiwaniu nazw własnych i pospolitych, a także skupiają się wokół procesów aktualizowania różnych kategorii w obrębie samych nazw własnych (osobowych, geograficznych, handlowych), gdzie próbuje się ustalić naturę relacji semantycznej między różnymi typami nazywanych obiektów [Crutch, Warrington 2004].

\subsection{Trudność aktualizowania nazw własnych w porównaniu z nazwami pospolitymi}

Istnieje kilka teorii na temat istotnej w zestawieniu $\mathrm{z}$ apelatywami trudności wyszukiwania nazw własnych. Według teorii (the set size of plausible phonology) Brennena [1993] przyczyną trudności z zapamiętaniem nazw własnych jest fakt wolniejszego tempa nabywania nowych nazw pospolitych $\mathrm{w}$ życiu dorosłym, a zwiększania się tempa uczenia nazwisk, co wiąże się z przyswajaniem szerszego zakresu różnego typu fonologii właściwej nazwom własnym a nie pospolitym.

Najczęściej problemy w wyszukiwaniu nazw własnych łączy się jednak z jednostkową semantyką nazw własnych, a ogólną nazw pospolitych. Badacze argumentują, że trudności $\mathrm{z}$ aktualizacją nazw własnych $\mathrm{z}$ jednoczesną sprawnością wyszukiwania nazw pospolitych są związane z semantycznymi właściwościami tej grupy nazw oraz z odrębnymi (i trudnymi) ścieżkami ich aktualizowania [Semenza 1997, 2006, 2009]. W literaturze podkreśla się ich semantyczną wyjątkowość (semantic uniqueness), rozumianą jako jednostkowość oraz - co charakterystyczne - brak znaczenia semantycznego [semantic meaningless, Yasuda, Nakamura, Beckman 2000]. Zdaniem badaczy relacja obiekt - nazwa jest wyjątkowo wrażliwa, bowiem w przypadku nazw pospolitych można mówić o szeroko rozpowszechnionych sieciach neuronalnych (widespread neuronal networks), które mogą być dostępne i aktywowane z różnych kognitywnych wejść [Semenza, Zettin 1989; Brédart 1993; Martins, Farrajota 2007: 1745].

\section{2. Źródła na poziomie semantycznym: charakter i sposób ujawnianej wiedzy}

Wobec podkreślanego przez neuropsychologów wąskiego zakresu znaczeniowego propriów, ich odsyłania jednostkowego [Semenza 2006: 890], należy jednak zwrócić większą uwagę na zawartość treściową nazw własnych, którą zaznacza się najczęściej w badaniach, lecz w celu wskazania na jej incydentalność, zindywidualizowanie i zarazem nieskończoną liczbę atrybutów [Yasuda, Nakamura, Beckman 2000: 1068].

W naszych badaniach zasugerowaliśmy, by zwrócić uwagę na relacje zachodzące między semantyką kategorialną oraz asocjacyjną ujawniającą się 
w produkcji samych nazw własnych. Semantyka kategorialna stanowi rodzaj podstawowej informacji na temat danej klasy wyrazów, która jest presuponowana (np. Jan Pawet II 'papież', Robert Kubica 'kierowca Formuły 1') lub pojawia się jako struktura apozycyjna (np. pies Atos, miasto Warszawa), a czasem nawet stanowi element samej nazwy własnej, por. the Atlantic Ocean, Mount Everest, jezioro Śniardwy [van Langendonck 2002: 925]. Zatem, dla zrozumienia nazw typu: Wisła, Kraków, Watęsa w słowniku mentalnym trzeba mieć pojęcia ogólne w rodzaju rzeka, miasto, osoba. To tzw. minimum znaczeniowe tkwiące w świadomości ludzi, składające się na ich wiedzę referencjalną (część wiedzy encyklopedycznej).

Poza tym minimum lokuje się jednak wyjątkowo rozległe znaczenie asocjacyjne (konotacja), jakie mają nazwy własne. Semantyka asocjacyjna ujawnia się w synchronicznej strukturze nazwy podczas jej odbioru, użycia, ponieważ odnosi się do poziomu parole, nie do poziomu langue [van Langendonck 2002: 925]. Te asocjacje mogą być dwojakiego rodzaju, mogą odnosić się do właściwości referenta (Wałęsa 'przyczynił się do obalenia komunizmu w Polsce') bądź jego nazwy (imię słowiańskie Sławomir pochodzi do sława i pokój i znaczy 'sławiący pokój’). Ten rodzaj znaczenia wzmocniony jest znaczeniem ekspresyjnym, które towarzyszy indywidualnie tworzonym się konotacjom do poszczególnych nazw. Osoby zdrowe sprawnie przywołują oba rodzaje wiedzy, u chorych ujawniają się różne zaburzenia, dysocjacje.

Sądzimy, że powodem, dla którego propria wyszukuje się znacznie trudniej, może być m.in. fakt obszernego znaczenia konotacyjnego, jakie ma nazwa własna. Zakres znaczeniowy propriów jest wąski, lecz ich treść jest wyjątkowo szeroka. Dowodem na poparcie niebezpośrednio mogą być wyniki badań Crutcha i Warrington [2004: 592], na podstawie których okazuje się, że najbardziej podobne reprezentacje semantyczne są mniej dostępne niż rzeczy mniej podobne. To z kolei podobieństwo może odpowiadać liczbie neuronów i synaps aktywowanych $\mathrm{w}$ trakcie prezentacji jednego lub dwóch stymulantów. Wobec powyższego, można uogólnić, że nazwy własne są znacznie trudniej dostępne, ponieważ wymagają aktywacji wielu różnych szlaków przebiegu informacji, a nie - jak się powszechnie sądzi - aktywacji tylko wybranego (arbitralnego) połączenia, powstałego na zasadzie jeden na jeden [one-to-one, Semenza, Zet-tin 1989].

Ponadto, jak pokazał drugi eksperyment, podczas którego chory aktualizował wiedzę na podstawie usłyszanej nazwy, trudnościom w nazywaniu towarzyszyły problemy ze wskazywaniem znaczenia kategorialnego, a zatem badany miał problemy z aktualizowaniem de facto apelatywnych określeń typu': aktor, prezydent,

${ }^{9}$ Trudny do wyjaśnienia jest także charakterystyczny rodzaj selektywnie ujawnianej wiedzy z zakresu denotacji, a zatem brak wiedzy kategorialnej w odniesieniu do nazw gór. Dotąd nie zajmowano się badaniem wyszukiwania tej kategorii nazw, tzw. oronimów, zatem nie mamy odniesienia do proce- 
malarz, pisarz, a nawet góry. Niewykluczone zatem, że dostęp do nazw własnych wymaga sprawnie działających dwukierunkowych połączeń referent-nazwa-wiedza o referencie. Problemy z przywołaniem nazwy wynikać mogą z przerwanych dróg odpowiadających znaczeniu zarówno kategorialnemu, jak i asocjacyjnemu.

\subsubsection{Denotacja i konotacja proprialna i apelatywna - specjalizacja półkulowa?}

Odmienny charakter wydobywanej wiedzy w poszczególnych eksperymentach wskazuje na wagę semantyki nazw własnych. Można by próbować określić specjalizację półkulową dla denotacji i konotacji proprialnej. Wiadomo dotąd z badań Brownela, Pottera, Michelowa [1984], że w odniesieniu do nazw pospolitych można mówić o mózgowej reprezentacji leksykalnego znaczenia denotacyjnego i konotacyjnego. Badani przez nich pacjenci z uszkodzoną prawą półkulą ${ }^{10}$ preferowali wybór słów powiązanych znaczeniem denotacyjnym, podczas gdy osoby z afazją wybierały słowa powiązane treściami konotacyjnymi. Grupa kontrolna z kolei dokonywała wyboru z użyciem obu kryteriów podziału. Badacze doszli na tej podstawie do wniosku, że przetwarzanie konotacyjnych znaczeń słów wiąże się z funkcjami prawej półkuli mózgu ${ }^{11}$.

W przypadku procesów wyszukiwania wiedzy podczas zaburzonej aktualizacji propriów zwraca uwagę odmienna konfiguracja aktualizowanej wiedzy, której należy poświęcić więcej uwagi.

\section{Podsumowanie}

Z przeprowadzonych badań wynika, że w modelu nazywania obiekt - wiedzanazwa istotne jest zróżnicowanie rodzaju wiedzy, tej określanej w literaturze jako wiedzieć coś o czymś i w mniejszym stopniu (bo rzadziej ujawnianej) wiedzieć kto? co? [Tranel 2009].

sów ich wyszukiwania u innych pacjentów. Wiemy natomiast więcej na temat wyszukiwania samych nazw geograficznych, które uchodzą za łatwiej aktualizowane w porównaniu z nazwami osób.

${ }^{10}$ Afazja występuje u pacjentów (praworęcznych) z uszkodzoną półkulą lewą. Rzadkie przypadki uszkodzeń w półkuli przeciwległej dotyczą osób z odmienną lateralizacją. Mówimy wówczas o afazji skrzyżowanej. Uszkodzenia półkuli prawej (u osób praworęcznych) mogą przyjąć postać pragnozji (dyspragmatyzmu). Nie wskazuje się tu (w przeciwieństwie do zaburzeń afatycznych) konkretnej struktury odpowiedzialnej za deficyty w zakresie kompetencji komunikacyjnej. Por. termin RHD patients 'right hemisphere damage patients' [Myers 2007: 91-99].

${ }^{11} \mathrm{~W}$ innych badaniach nad semantyką apelatywów w zaburzeniach prawopółkulowych wysunięto hipotezę przeciwną prostej dychotomii denotacja - konotacja. Tompkins i Jackson [Academy of Aphasia 1988 za: Goulett 1990] upatrywali trudności semantycznych w dychotomii dowolne automatyczne przetwarzanie informacji. W rezultacie okazało się, że pacjenci z uszkodzeniami prawostronnymi zachowują zdolność do prawidłowego przetwarzania znaczeń konotacyjnych na poziomie automatycznym. Zatem ich zaburzenia mogą dotyczyć świadomego przetwarzania znaczeń. 
Opisany eksperyment rejestrował charakter ujawnianego się znaczenia denotacyjnego i konotacyjnego podczas bodźcowania nazwą oraz obrazem denotatu. W procesie nazywania potwierdziła się wskazywana w literaturze łatwość i bezbłędność wyszukiwania na drodze nazwa - obraz referenta (testy wielokrotnego wyboru). Niezaburzona okazała się także relacja wiedza - obraz referenta (test wielokrotnego wyboru). Zatem drogi kierujące się do obrazu referenta należą do najsilniej skojarzonych i trudnych do uszkodzenia (por. rys. 3). Znacznie bardziej wrażliwe są ścieżki, których źródłem jest obraz referenta oraz nazwa mająca wywołać określoną wiedzę na temat oznaczonego nią referenta.

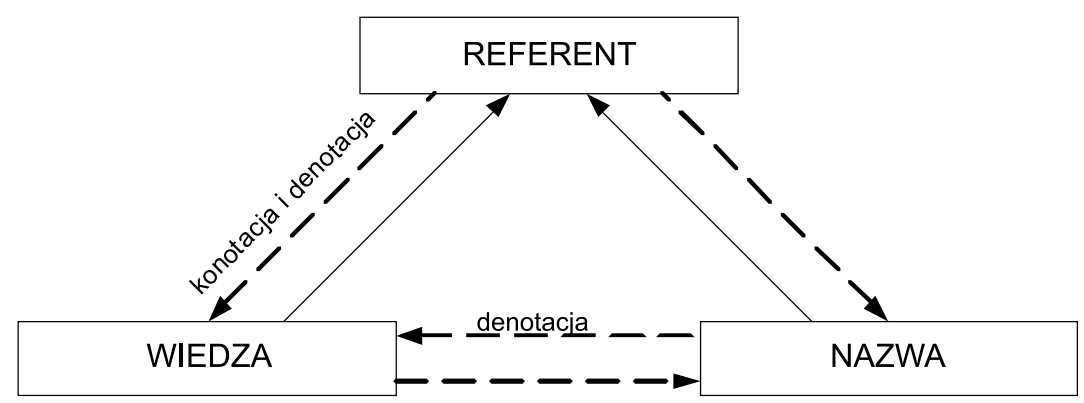

Rys. 3. Model ujawnianej wiedzy podczas zaburzonego procesu aktualizowania propriów (linia przerywana - zaburzony przebieg informacji, linia ciagła - sprawny przebieg informacji)

Jak się okazało, w sytuacji gdy bodźcem był obraz referenta, pacjent prezentował wiedzę zarówno o charakterze denotacji, jak i konotacji, przy czym konotacja nieznacznie przeważała. Ten zatem rodzaj wiedzy ujawnia się w sytuacji, gdy patrzymy na dany obiekt. Nie była to jednak przewaga znacząca. Zatem, na drodze obraz referenta - nazwa zapewne wszystkie rodzaje wiedzy wydobywa się łatwiej, z niewielką przewagą konotacji.

Odmiennie przedstawiał się charakter przywoływanej wiedzy na drodze od nazwy do wiedzy o tak nazwanym referencie. Wówczas pacjent podawał jedynie znaczenie denotacyjne, które ponadto było selektywne i regularnie zaburzone. Chory nie był w stanie wskazać żadnego rodzaju wiedzy odnoszącej się do nazw osobowych oraz nazw gór. Nie mógł ich przywołać także w czasie prezentacji $\mathrm{z}$ udziałem fotografii. Zatem trudności aktualizowania nazw własnych mogą wynikać z zaburzonego dostępu do wiedzy kategorialnej, o typie denotacji. To należy do minimum znaczeniowego nazw własnych. Denotacja także na poziomie obraz referenta - nazwa ujawniała się częściej z błędami niż konotacja.

Niewykluczone, że do sprawnego wyszukiwania nazw własnych uruchamiać się muszą wszystkie ścieżki referencji. W momencie, gdy traci się chociażby jedną z nich z powodu urazu czy wieku (chorób zwyrodnieniowych mózgu), zaczyna wadliwie działać system połączeń pozwalający na aktualizację propriów. 


\section{Bibliografia}

Beeching Cyril Leslie, 1982, A dictionary of eponyms, London.

Brennen Tim, 1993, The difficulty with recalling people's names: The plausible phonology hypothesis, „Memory” 1, 409-431.

Crutch Sebastian, Warrington Elizabeth, 2004, The semantic organization of proper nouns: the case of people and brand names, „Neuropsychologia” 42, 584-596.

Cipolotti Lisa, 2000, Sparing of country and nationality names in a case of modality-specific oral output impairment: implications for theories of speed production, „Cognitive Neuropsychology" 17(8), 709-729.

Freeman Marton, 1997, A new dictionnary of eponyms, New York-Oxford.

Glucksberg Sam, Haught Catrinel, 2006, Can Florida became like the next Florida? When metaphoric comparisions fail, „Psychological Science” 17(11), 935-938.

Goosens Louis, 1990, Metaphtonymy: The interaction of metaphor and metonymy in expressions for linguistic action, „Cognitive Linguistics” 1, 323-340.

Kripke Saul, 1980, Naming and Necessity, Oxford.

Langendonck Willy van, 2002, Neurolinguistics evidence for basic level and associative meaning in proper names, [w:] Ana Isabel Boullón Agrelo (red.), Actas Del XX Congreso Internacional De Ciencias Onomasticas, Santiago 1999, A Coruña, 921-927.

Martins Isabel Pavão, Farrajota Luisa, 2007, Proper and common names: A double dissociation, „Neuropsychologia” 45, 1744-1756.

Mill John Stuart, 1843, System of Logic, Ratiocinative and Inductive, vol. 1, London.

Myers Penelope S., 2007, Right Hemisphere Damage. Disorders of Communication and Cognition, New York.

Otin Evgenij Stepanovič, 2004, Slovar konnotativnych sobstviennych imien, Donieck.

Pąchalska Maria, 2011, Afazjologia, Warszawa.

Robson Jo, Marshall Jane, Pring Tim, Montagu Ann, 2004, Processing proper nouns in aphasia: Evidence from assessment and therapy, „Aphasiology” 18 (10), 917-935.

Russell Bertrand, 1919, Introduction to mathematical philosophy of language, London.

Rutkiewicz-Hanczewska Małgorzata, 2014, Komunikacja niewerbalna w afazji oraz sposoby jej wspomagania systemem MAKATON jako forma terapii językowej, [w:] Bogusława Beata Kaczmarek (red.), Makaton w rozwoju osób ze złożonymi potrzebami komunikacyjnymi, Kraków, 233-257.

Rutkowski Mariusz, 2012, Stownik metafor i konotacji nazw własnych, Olsztyn.

Schmidt Darren, Buchanan Lori, Semenza Carlo, 2004, Sparing of proper nouns and dates in aphasia, ,Brain and Language” 91(1), 9-10.

Searle John, 1971, The problem of proper names, ,Semantics. An interdisciplinary reader in philosophy, linguistics and psychology", London, 134-141.

Semenza Carlo, 1997, Proper name - specific aphasias, [w:] Harold Goodglass, Arthur Wingfield (eds.), Anomia. Neuroanatomical and Cognitive Correlates, San Diego, 115-134.

Semenza Carlo, 2006, Retrieval pathways for common and proper names, „Cortex” 42, 884-891.

Semenza Carlo, 2009, The neuropsychology of proper names, „Mind \& Language” 24(4), 347-369.

Semenza Carlo, Zettin Marina, 1988, Generating proper names: a case of selective inability, „Cognitive Neuropsychology" 5, 711-721.

Semenza Carlo, Zettin Marina, 1989, Evidence from aphasia for proper names as pure referring expressions, „Nature” 342 (6250), 678-679.

Valentine Tim, Brennen Tim, Brédart Serge, 1996, The Cognitive Psychology of Proper Names. On the importance of being Ernest, London-New York.

Yasuda Kiyoshi, Nakamura Tetsuo, Beckman Bobbie, 2000, Brain processing of proper names, „Aphasiology” 14(11), 1067-1089. 
Małgorzata Rutkiewicz-Hanczewska

\title{
Proper names semantics in neurolinguistical depiction
}

\author{
(Summary)
}

The paper presents latest research results in the field of cognitive psychology of proper names. The goal of this paper is proper names semantics characteristic (toponymy, anthroponymy) provided on the base of experiments with aphate with proper anomia, in other words the proper names retrieval disorders with common names sparing.

In the research we present the proper names retrieval model especially on semantic level and in particular denotation and connotation.

Słowa kluczowe: anomia, nazwy własne, wyszukiwanie nazw, poziom semantyczny, afazja

Keywords: anomia, proper names, name retrieval, semantic level, aphasia 